\title{
Integrated Nutrient Management in Marigold (Tagetes erecta L.) cv. Pusa Narangi Gainda
}

\author{
Anu Seng Chaupoo ${ }^{1}$ and Sunil Kumar ${ }^{2^{*}}$ \\ ${ }^{1}$ Department of Horticulture, North Eastern Hill University, \\ Tura Campus, Tura-794 002, West Garo Hills District, Meghalaya, India \\ ${ }^{2}$ Department of Floriculture \& Landscape Architecture, \\ College of Horticulture \& Forestry, Central Agricultural University, \\ Pasighat-791 102, East Siang District, Arunachal Pradesh, India \\ *Corresponding author
}

\section{A B S T R A C T}

\begin{tabular}{|l|}
\hline K e y w o r d s \\
Marigold, Manure, \\
Biofertilizers, \\
Growth, Quality, \\
Yield \\
\hline Article Info \\
\hline $\begin{array}{l}\text { Accepted: } \\
23 \text { April } 2020 \\
\text { Available Online: } \\
\text { 10 May 2020 }\end{array}$ \\
\hline
\end{tabular}

\begin{abstract}
An investigation was carried out to study the combined effect of organic fertilizers and bio-fertilizers on the vegetative and flowering characters of marigold (Tagetes erecta $\mathrm{L}$.) cv. PusaNarangiGaindaat the horticultural instructional farm, NEHU, Tura campus, Chasingre, Meghalaya during the year 2017-18. The experiment was conducted in randomized complete block design (RCBD) with three replications and twelve treatment combinations comprising of FYM, vermicompost and biofertilizers viz. Azotobacter and Azospirillum. All the treatment combinations showed significant response in vegetative, flowering and yield characters during entire investigation. The treatment combinations Azospirillum + Azotobacter + vermicompost $+50 \%$ RDF showed maximum plant height $(106.25 \mathrm{~cm})$, primary and secondary branches $(16.83$ and 22.00$)$, leaf area $\left(62.11 \mathrm{~cm}^{2}\right)$ and plant spread $(53.56 \mathrm{~cm} \mathrm{E-W}$ and $46.03 \mathrm{~cm} \mathrm{~N}-\mathrm{S}$ ) per plant,number of flowers per plant (30.50), flower yield per plant $(326.05 \mathrm{~g})$, flower yield $(293.44 \mathrm{q} / \mathrm{ha})$ and seed yield $(14.67 \mathrm{~kg} / \mathrm{ha})$, whilst highestleaf length and breadth $(15.91 \mathrm{~cm}$ and $3.95 \mathrm{~cm})$, increased flower diameter $(60.25 \mathrm{~mm})$, enhanced flower bud initiation (53.67 days) and prolonged duration of flowering (103.33 days)was associated with Azospirillum + Azotobacter + FYM + 50\% RDF. Maximum carotenoid content in fresh petals $(11.65 \mathrm{mg} / 100 \mathrm{~g}$ fresh petals $)$ and dry petals $(11.37 \mathrm{mg} / 100 \mathrm{~g}$ dry petals) was associated with treatment Azospirillum + Azotobacter + vermicompost $+50 \%$ RDF), however, chlorophyll B (61.92 mg/g leaves) content was recorded to be highest in the treatment Azospirillum + Azotobacter + FYM + 50\% RDF).
\end{abstract}

\section{Introduction}

Marigold (Tagetes erecta L.) is most important flower crops commercially grown in India. Marigold gains popularity among flower growers due to its easy cultivation, wide adaptability to diverse soil and climatic conditions, habit of profuse flowering, short duration to produce marketable flowers, eclectic spectrum of attractive colours, shape and good keeping quality. Flowers are extensively used as loose form for floral decoration, religious offerings, garlands making and flower baskets.

Besides its ornamental value, marigold petals are concentrated source of xanthophylls and a rich source of lutein (80-90 per cent). Dry petal of marigold flower contains about 90 per cent (w/w) carotenoids. 
These dried petals or concentrates are used as feed additives to improve the pigmentation of the poultry skin and the eggs of laying hens. Nutritional management through organic manure is helpful for enhancing growth, yield and quality of marigold flowers (Kumar and Sharma 2013). Generally, marigold responds very well to the application of inorganic and organic fertilizers.

Nutritional management through organic manure are helpful for enhancing growth, yield and quality of flowers. However, indiscriminate and long term use of fertilizer have resulted in deterioration of soil health in terms of its physical and chemical properties, reduction in organic content, soil humus, decline in soil microbial activities and increased pollution hazards of soil, water and air besides causing health hazards to a society and has it also affected the growth and production of flowers.

Bio-fertilizer usually consists of live or latent cells of micro-organisms which include biological nitrogen fixers, P-solubilizing, mineralization of nitrogen and transformation of several elements into available forms. VAM, Azotobacter, Azospirillum and phosphate solubilizing bacteria are regularly applied bio-fertilizers in horticultural crops (Zaredost et al., 2014). Use of bio-fertilizers lessens per unit consumption of inorganic fertilizers and upsurges the quality and quantity of flowers (Syamal et al., 2006).

Bio-fertilizers help in the fixation of atmospheric nitrogen as well as improving phosphorus uptake by plants (Kumar et al., 2006). Vermicompost and farm yard manure (FYM) proved to be beneficial to fix atmospheric nitrogen and solubilize fixed phosphorus in soil and also secrete growth substances like auxins, which stimulated the plant metabolic activities and photosynthetic efficacy leading to better growth and development of plant. Yadav et al., (2017) noticed that growth and yield attributes increased with bio- fertilizers in marigold.

Organic and bio-fertilizer like vermicompost, farm yard manure azotobacter and azospirillum plays an important role in improving the plant growth because of major constituent in chlorophyll, protein and amino acids, resulted in increased production of green leaves.

The combined application of Azotobacter, phosphate solubilizing bacteria, Azospirillum, FYM and Vermicompost along with nitrogen and phosphorus has been provento be beneficial for robust growth of plants. Studies indicate the greater influence of organic fertilizers on growth, flower production and quality blooms in many ornamental flowering plants. The integrated soil fertility management practices involving judicious combination of organic manures, bio fertilizers and chemical fertilizers seems to be a feasible option for sustained agriculture on a commercial and profitable scale (Singh et al., 2015).

The yield and quality of marigold flowers may be improved by espousing integrated nutrient management practices which include the judicious and combined use of organic, inorganic and bio-fertilizers. The research over conventional nutritional requirement (recommended dose of NPK fertilizers) has been standardized. However, systematic research and documentation on the effect of organic sources of nutrient for marigold is still lacking. Therefore, the present investigation has been carried out to find out the suitable treatment to get the maximum vegetative growth, flowering and yield of marigold (Tagetes erecta L.) cv. Pusa Narangi Gainda under the agro-climatic conditions of Tura, West Garo Hills, Meghalaya. 


\section{Materials and Methods}

The experiment was carried out at the experimental farm of Department of Horticulture, NEHU, Tura campus, Chasingre, Meghalaya from September, 2017 to April 2018. The district is located approximately between the latitudes $90^{\circ} 30^{\prime}$ and $89^{\circ} 40^{\prime} \mathrm{E}$ and the longitudes of $26^{\circ}$ and $25^{\circ} 20^{\prime} \mathrm{N}$ with an average elevation of 349 metres (1145 feet).The prevailing weather of the region is sub-tropical, experiences a relatively high temperature in summer and cool winters. The average rainfall of the district is $3300 \mathrm{~mm}$, of which more than two-third occurs during the monsoon, however, winter being practically dry.

Twelve treatments viz.Control (100\% RDF), Azospirillum $+75 \%$ RD ' $\mathrm{N}$ ' $+100 \%$ RD ' $\mathrm{P}$ ' and ' $\mathrm{K}$ ', Azotobacter $+75 \%$ RD 'P' $+100 \%$ $\mathrm{RD}$ ' $\mathrm{N}$ ' and ' $\mathrm{K}$ ', $\mathrm{FYM}+50 \% \mathrm{RDF}, \mathrm{VC}+$ $50 \%$ RDF, Azospirillum + FYM +50\% RDF, Azospirillum $+\mathrm{VC}+50 \%$ RDF, Azotobacter $+\mathrm{FYM}+50 \%$ RDF, Azotobacter +VC $+50 \%$ RDF, Azospirillum + Azotobacter $+50 \%$ $\mathrm{RD}$ 'N' and 'P' $+100 \% \quad \mathrm{RD}$ ' $\mathrm{K}$ ', Azospirillum + Azotobacter + FYM $+50 \%$ $\mathrm{RDF}$ and Azospirillum + Azotobacter $+\mathrm{VC}$ $+50 \%$ RDFwere compared to find out suitable dose of integrated nutrients under agroclimatic conditions of Tura.

Recommended dose of nitrogen $(120 \mathrm{~kg} / \mathrm{ha})$, phosphorous $(80 \mathrm{~kg} / \mathrm{ha})$, potassium $(60 \mathrm{~kg} / \mathrm{ha})$ in the form of urea, single super phosphate (SSP), murate of potash (MOP), respectively, well decomposed FYM @ 25 t/ha, vermicompost @2.5 t/ha and biofertilizers@ $5 \mathrm{~kg} / \mathrm{ha}$ were incorporated into the soil before transplanting. The suitable combinations of organic and inorganic fertilizers were applied basal before transplanting. The experiment was conducted in randomized completely block design (RCBD) with three replications.
Uniform size $(10-15 \mathrm{~cm})$ of marigold seedlings cv. Pusa narangigainda was transplanted on raised beds at spacing $30 \times 30 \mathrm{~cm}$. The observations on vegetative and flowering characters viz. plant height, number of primary branch, number of secondary branch, leaf length, leaf breadth, leaf area, plant spread, initiation of flower buds, flowering duration, flower diameter, number of flowers per plant, flower yield per plant, flower yield, fresh weight of flower and seed yield were recorded and analysed statistically as suggested by (Gomez and Gomez, 2010). Chlorophyll-A and Chlorophyll-B content of leaf tissue and carotenoid were determined by using the method described by (Sadasivam and Manickam, 2005).

\section{Results and Discussion}

Response of organic manures and biofertilizers on vegetative growth characters

Both vegetative and floral characters were found to be improved by integrated nutrient management. Significant response of organic manures and bio-fertilizers on growth characters are presented (Table 1, Fig. 1). The maximum plant height $(106.91 \mathrm{~cm})$ was associated with application of Azotobacter + Vermicompost $+50 \%$ RDF which was at par with Azospirillum + Azotobacter + Vermicompost $+50 \%$ RDF $(106.25 \mathrm{~cm})$ and Azotobacter + FYM + 50\% RDF $(106.63 \mathrm{~cm})$.

The increase in plant height with combination of organic manure and bio-fertilizers might be due to the upsurge in transport of metabolites and rate of photosynthesis in the plant, which empowers the plant for quick and better upward vegetative growth. Combination of organic manure and bio-fertilizers proved to be the best for attaining the maximum plant height (Keisam et al., 2014; Swaroop et al., 2017) in gladiolus. 
Nutrient management through judicious combination of organic manure, bio-fertilizers and inorganic fertilizers showed significant response in number of branches per plant. More number of primary branches per plant (19.33) was found in Azospirillum+ Azotobacter + FYM + 50\% RDF which was at par with Azotobacter + FYM $+50 \%$ RDF (19.00) and Azospirillum+ Azotobacter + Vermicompost $+50 \%$ RDF (16.83). Use of organic manures and biofertilizers helps for maximum number of primary branches and plant spread in China aster (Bohra et al., 2019).

However, number of secondary branches per plant (22.00) was found in Azospirillum+ Azotobacter + Vermicompost $+50 \%$ RDFwhich was at par with Azospirillum+ Azotobacter $+\mathrm{FYM}+50 \% \mathrm{RDF}$ (19.67).Increased leaf length and leaf breadth was observed in treatment combinations of Azospirillum + Azotobacter + FYM $+50 \%$ RDF $(15.91 \mathrm{~cm}$ and $3.95 \mathrm{~cm})$ which was at par with Azospirillum+ Azotobacter + Vermicompost $+50 \%$ RDF $(15.56 \mathrm{~cm}$ and $3.57 \mathrm{~cm})$ and Azotobacter $+\mathrm{FYM}+50 \% \mathrm{RDF}$ $(15.05 \mathrm{~cm}$ and $3.88 \mathrm{~cm})$. Whereas, increased leaf area was observed in the plot which receivedAzospirillum+ Azotobacter + Vermicompost $+50 \%$ RDF $\left(62.11 \mathrm{~cm}^{2}\right)$ followed by Azospirillum+ $75 \%$ RD 'N'+100\% RD 'P' and ' $\mathrm{K}$ ' $\left(50.81 \mathrm{~cm}^{2}\right)$ and Azotobacter + FYM + 50\% RDF $\left(49.38 \mathrm{~cm}^{2}\right)$. Dubliya et al., (2018) also observed maximum leaf area per plant in tuberose from integrated nutrient management with vermicompost, Azotobacter and RDF.

The application of Azospirillum+ Azotobacter + Vermicompost $+50 \%$ RDF showed maximum E-W and N-S plant spread $(53.56 \mathrm{~cm}$ and $46.03 \mathrm{~cm})$ followed by Azospirillum + FYM + 50\% RDF $(43.03 \mathrm{~cm}$ and $41.96 \mathrm{~cm}$ ) and Azospirillum+ Azotobacter $+\mathrm{FYM}+50 \%$ RDF $(39.87 \mathrm{~cm}$ and $40.30 \mathrm{~cm})$.
Better performance of vegetative parameters viz. plant height, number of primary and secondary branches, plant spread, leaf length, breadth and area were observed when the plants were treated with biofertilizers and organic manures in combination with $50 \%$ RDF. Vermicompost or FYM enhances soil fertility and moisture retention capacity of soil favorable to plant growth which might have contributed to the increase in plant height and leaf area.

These findings are in close conformity with the result of tuberose (Chawla et al., 2018), marigold (Sharma et al., 2017), dahlia (Pandey et al., 2017) and marigold (Singh et al., 2015). Application of vermicompost along with biofertilizers and RDF may be attributed to microbial decomposition resulting in enhanced availability of nutrients which was translocated from soil to the plants during the entire growing season favoring the stimulation and production of auxiliary buds resulting in formation of a greater number of leaves in marigold (Pooja et al., 2012).Significant response in vegetative growth, flowering characters and biochemical parameters and yield characters also observed in china aster (Kumar et al., 2016) and marigold (Tomar et al., 2013).

Response of organic manures and biofertilizers on flowering and yield characters

Significant responses of organic manures and bio-fertilizers on flowering characters are presented (Table 2, Fig. 2). Earliness in flower bud initiation showed by Vermicompost $+50 \%$ RDF (44.67 days) followed by Azospirillum + Vermicompost + $50 \%$ RDF (50.00 days), but was on par with Azospirillum+Azotobacter + Vermicompost $+50 \%$ RDF (46.17 days). The delayed flowering was observed in control (74.00 days). 
Earliness in flower bud initiation with organic manure and bio-fertilizer applications was also observed by Keisam et al., (2014) in gladiolus, Kumari et al., (2014) in chrysanthemum and Zaredost et al., (2014) in marigold. Early emergence of flower buds on application of vermicompost along with RDF might be due to increased availability of nitrogen, easy uptake of nutrients and simultaneous transport of growth promoting substances like cytokinin to the axillary buds resulting in breakage of apical dominance and facilitated better sink for faster mobilization of photosynthates and early transformation of plant parts from vegetative to reproductive phase. The present findings are lent credence to the observation of Munikrishnappa et al., (2004); Subha (2006); Kumar et al., (2016).

Prolonged duration of flowering was noticed under treatment with Azospirillum + Azotobacter + Vermicompost $+50 \%$ RDF (103.33 days) followed by Azospirillum+ FYM +50\% RDF (98.33 days), but was on par with Azospirillum +Azotobacter+FYM $+50 \%$ RDF (100.00 days). While, reduced number of days for bloom was associated with Azospirillum + 50\% RD 'N' + 100\% RD $\mathrm{N} \& \mathrm{~K}$ (65.50 days). Reduction in days taken for flowering was also reported by Pandey et al., (2010) in chrysanthemum, Kumar and Sharma (2013) in marigold and Kumar et al., (2015) in Dendrobium orchid.

However, Maximum flower diameter was associated with Azospirillum + Azotobacter + FYM $+50 \%$ RD(60.25 mm) which was on par with Azospirillum + Azotobacter + Vermicompost $+50 \%$ RDF (58.04 mm) and Azotobacter+ Vermicompost $+50 \%$ $\mathrm{RDF}(59.91 \mathrm{~mm})$, whereas, minimum flower diameter was noticed under control $(49.12 \mathrm{~mm})$. The beneficial effect on earliness in flower bud initiation, large sized flower and number of flower buds might be due to early breaking of apical dominance followed by easy and better translocation of nutrients to the flowers, better plant growth by the increased availability of nutrients and accelerated mobility of photosynthates from source to sink as influenced by the growth hormones released or synthesized from organic manures and bio-fertilizers. Application of vermicompost or FYM along with Azotobacter and Azospirillum proved to give longer flowering duration, flower diameter and higher flower production which in turn is beneficial for flower yield.

Vermicompost and FYM not only supports the survivability of microbes but also helps in their further multiplication as a result improves the flowering quality of the plant. These results corroborate with the findings of Panchal et al., (2010) in chrysanthemum, Deshmukh et al., (2008) in gaillardia; Shashidhara and Gopinath (2005) in calendula; Singh et al., (2015) in marigold.

The present research revealed that application of organic manures and bio-fertilizers along with inorganic fertilizers influenced significantly the quality of flower. Application of Azospirillum + Azotobacter + Vermicompost $+50 \%$ RDF produced highest number of flower buds per plant (30.50) followed by Azospirillum+ Azotobacter + FYM+50\% RDF(27.17) and Azospirillum+ $\mathrm{FYM}+50 \% \operatorname{RDF}(25.50)$.

Increased number of flower buds might be due to better nutrient uptake, higher photosynthetic efficiency, source-sink relationship and supply of macro and micro nutrients, enzymes and growth hormones. Similar results were noticed by several workers viz. Ali et al., (2014) stated that application of biofertilizers resulted in the maximum number of flowers in gladiolus. Keisam et al., (2014) also reported the maximum length of flower stalk, number of flowers per plant and flower weight in 
gladiolus was obtained with the application of organic nutrients. The nitrogenous compounds such as amino acids may have synthesized as influenced by the phytohormones released due to the application of chemical and biofertilizers. This amino acid act as a precursor of polyamines and secondary messenger in the flower initiation and development of more numbers of flower buds per plants in marigold (Kumar et al., 2016).

Use of Azospirillum + Azotobacter + FYM + $50 \%$ RDF showed increased fresh weight of single flower $(11.07 \mathrm{~g})$ which was on par with Azospirillum + Azotobacter + Vermicompost $+50 \%$ RDF (10.69g) and followed by Azotobacter $+75 \%$ RD P $+100 \%$ RD N and K (9.25g). Hadwani et al., (2013) noticed that integrated nutrient management resulted in the longest flowering duration. Application of organic manure and biofertilizers responded for maximum number of flowers and increased fresh weight might be due to the direct response of organic fertilization which may promote cell proliferation efficiently. Cell division and cell enlargement are accelerated by ample supply of nitrogen which initiates meristematic activity in crops (Crowther, 1935).

Abundant supply of organic manure and biofertilizers might have accelerated the photosynthetic activities of the plants and more assimilates may have translocated into flowers to develop, resulting in increased fresh weight of the flower. Zaredost et al., (2014) observed that combined effect of bioand chemical fertilizers resulted in the maximum fresh weight of flower in marigold. Enhanced flower yield was noted with Azospirillum + Azotobacter + Vermicompost $+50 \%$ RDF (326.05g and 293.44q/ha) followed by Azospirillum+ Azotobacter + $50 \%$ RD' $\mathrm{N}$ ' and 'P'+ 100\% RDF (244.56g and $220.10 \mathrm{q} / \mathrm{ha}$ ) which was on par with Azospirillum + Azotobacter + Vermicompost + $50 \%$ RDF (273.04g and $225.00 \mathrm{q} / \mathrm{ha}$ ), while, lowest flower yield was associated with control (207.76g and $186.98 \mathrm{q} / \mathrm{ha})$. Increased flower yield had also been observed in chrysanthemum (Aashutosh et al., 2019).

Whereas, maximum seed yield was obtained from the treatment combination of Azospirillum + Azotobacter + FYM $+50 \%$ RDF $(14.67 \mathrm{q} / \mathrm{ha})$ which was on par with Azospirillum + Azotobacter + Vermicompost $+50 \% \mathrm{RDF}(13.41 \mathrm{q} / \mathrm{ha})$. These results are in close conformity with the findings of Thumar et al., (2013) in marigold; Mittal et al., (2010) in marigold; Parya et al., (2010) in golden rod; Sharma et al., (2009) in China aster which revealed that application of organic manures and biofertilizers increased significantly flower yield per plant and flower yield per hectare might be due to conversion of photosynthates into proteins resulted in more flower primordia and development of flower buds.

\section{Response of organic manures and bio- fertilizers on biochemical characters}

Significant responses in Chlorophyll and carotenoid contents in fresh petals as well as dry petals of various treatment combinations are presented (Table 3, Fig. 3). All the treatment combinations for chlorophyll A content was non-significant, whilst Azospirillum + Azotobacter + FYM $+50 \%$ RDFshowed increased chlorophyll B content $(61.92 \mathrm{mg} / \mathrm{g})$ followed by Azospirillum+ Azotobacter + Vermicompost $+50 \%$ RDF $(57.76 \mathrm{mg} / \mathrm{g})$ and $\mathrm{FYM}+50 \% \mathrm{RDF}$ $(49.27 \mathrm{mg} / \mathrm{g})$. Vermicompost had significant effect on photosynthetic pigments and imparts highest content of chlorophyll and carotenoids in marigold (Sardoei et al., 2014). 
Table.1 Effect of integrated nutrient management on vegetative parameters of marigold at Tura, West Garo Hills district, Meghalaya

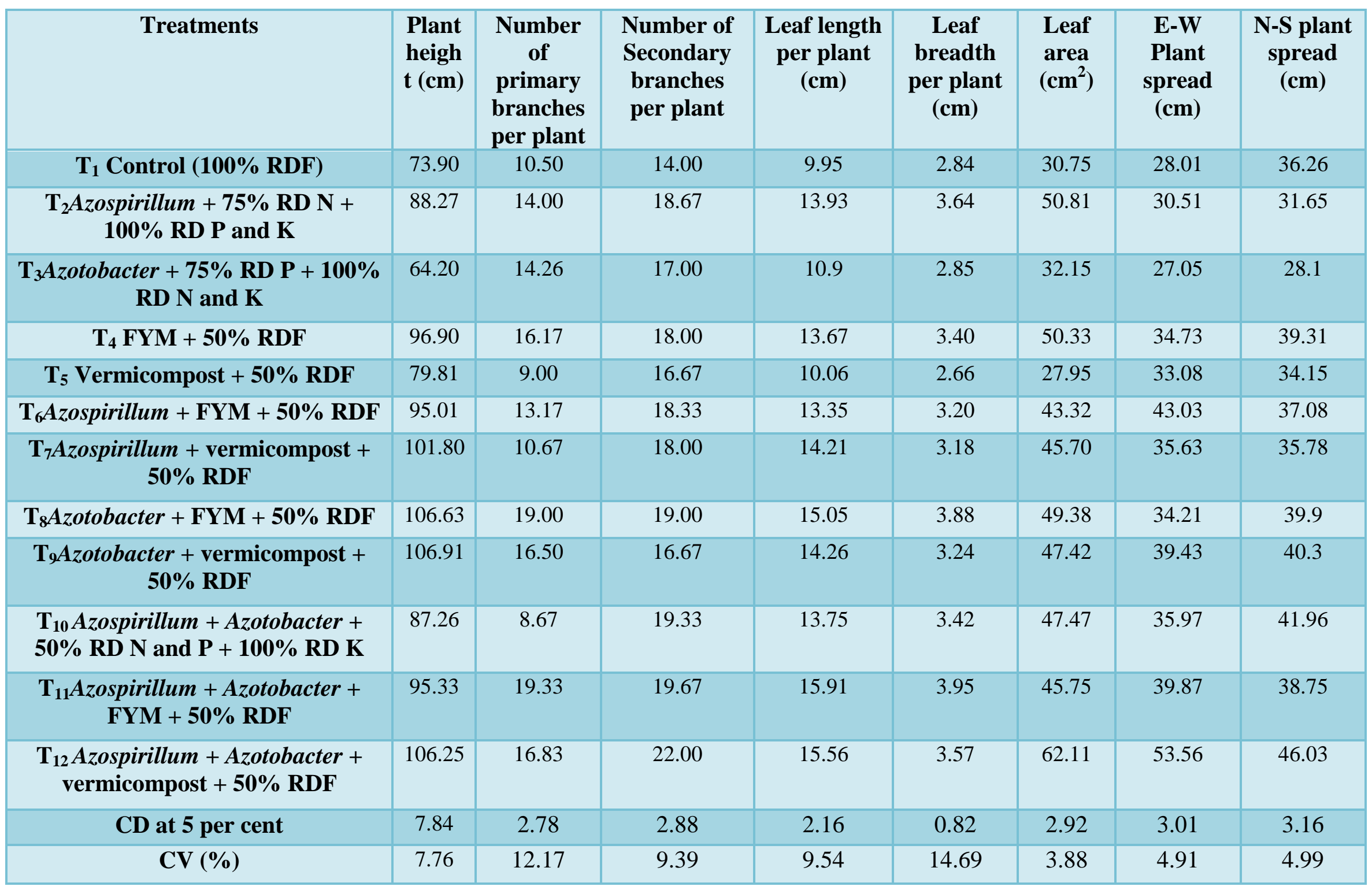


Table.2 Effect of integrated nutrient management on flowering parameters of marigold at Tura, West Garo Hills district, Meghalaya

\begin{tabular}{|c|c|c|c|c|c|c|c|c|}
\hline Treatments & $\begin{array}{l}\text { Flower } \\
\text { bud } \\
\text { initiatio } \\
\text { n (days) }\end{array}$ & $\begin{array}{l}\text { Flowerin } \\
\text { g } \\
\text { duration } \\
\text { (days) }\end{array}$ & $\begin{array}{l}\text { Flower } \\
\text { diamete } \\
\mathbf{r}(\mathbf{m m})\end{array}$ & $\begin{array}{l}\text { Number } \\
\text { of } \\
\text { flowers } \\
\text { /plant }\end{array}$ & $\begin{array}{l}\text { Flower } \\
\text { yield per } \\
\text { plant } \\
\text { (g) }\end{array}$ & $\begin{array}{l}\text { Flower } \\
\text { yield } \\
\text { (q/ha) }\end{array}$ & $\begin{array}{c}\text { Fresh } \\
\text { weight of } \\
\text { flower (g) }\end{array}$ & $\begin{array}{c}\text { Seed } \\
\text { yield } \\
\text { (q/ha) }\end{array}$ \\
\hline $\mathrm{T}_{1}$ Control (100\% RDF) & 74.00 & 89.33 & 49.12 & 24.50 & 207.76 & 186.98 & 8.48 & 10.90 \\
\hline $\begin{array}{c}\mathrm{T}_{2} \text { Azospirillum }+75 \% \text { RD N } \\
+100 \% \text { RD P and K }\end{array}$ & 50.00 & 65.50 & 52.99 & 26.25 & 242.81 & 218.53 & 9.25 & 8.59 \\
\hline $\begin{array}{c}\mathrm{T}_{3} \text { Azotobacter }+75 \% \text { RD P + } \\
100 \% \text { RD N and K }\end{array}$ & 69.00 & 66.00 & 52.91 & 23.83 & 219.47 & 197.53 & 9.21 & 9.30 \\
\hline $\mathrm{T}_{4} \mathrm{FYM}+\mathbf{5 0 \%} \mathrm{RDF}$ & 50.50 & 92.33 & 56.28 & 25.33 & 265.46 & 238.91 & 10.48 & 12.30 \\
\hline $\begin{array}{c}\text { T }_{5} \text { Vermicompost }+50 \% \\
\text { RDF }\end{array}$ & 44.67 & 101.33 & 54.60 & 26.33 & 275.68 & 248.11 & 10.47 & 9.94 \\
\hline $\begin{array}{c}\text { T }_{6} \text { Azospirillum }+ \text { FYM }+50 \% \\
\text { RDF }\end{array}$ & 47.67 & 98.33 & 56.56 & 25.50 & 257.55 & 231.80 & 10.10 & 9.61 \\
\hline $\begin{array}{c}\mathrm{T}_{7} \text { Azospirillum }+ \\
\text { vermicompost }+\mathbf{5 0 \%} \mathrm{RDF}\end{array}$ & 50.00 & 96.00 & 58.48 & 27.00 & 284.04 & 255.64 & 10.52 & 12.76 \\
\hline $\begin{array}{c}\text { T }_{8} \text { Azotobacter }+ \text { FYM }+50 \% \\
\text { RDF }\end{array}$ & 58.33 & 87.67 & 50.72 & 26.33 & 250.00 & 245.74 & 10.37 & 9.78 \\
\hline $\begin{array}{c}\mathrm{T}_{9} \text { Azotobacter }+ \\
\text { vermicompost }+\mathbf{5 0 \%} \mathrm{RDF}\end{array}$ & 54.17 & 91.83 & 59.91 & 25.00 & 300.77 & 270.69 & 10.00 & 10.25 \\
\hline $\begin{array}{c}\text { T }_{10} \text { Azospirillum }+ \text { Azotobacter } \\
+50 \% \text { RD N and P }+100 \% \\
\text { RD K }\end{array}$ & 60.33 & 87.33 & 56.08 & 24.00 & 244.56 & 220.10 & 10.19 & 14.44 \\
\hline $\begin{array}{c}\text { T }_{11} \text { Azospirillum + Azotobacter } \\
+ \text { FYM + 50\% RDF }\end{array}$ & 53.67 & 100.00 & 60.25 & 27.17 & 273.04 & 225.00 & 11.07 & 14.67 \\
\hline $\begin{array}{l}\mathrm{T}_{12} \text { Azospirillum }+ \text { Azotobacter } \\
+ \text { vermicompost }+50 \% \mathrm{RDF}\end{array}$ & 46.17 & 103.33 & 58.04 & 30.50 & 326.05 & 293.44 & 10.69 & 13.41 \\
\hline CD at 5 per cent & 2.55 & 3.48 & 2.63 & 0.97 & 10.47 & 23.99 & 0.77 & 2.78 \\
\hline CV (\%) & 2.74 & 2.29 & 2.79 & 9.63 & 4.12 & 8.49 & 14.75 & 7.48 \\
\hline
\end{tabular}


Table.3 Effect of integrated nutrient management on bio-chemical parameters of marigold at Tura,

West Garo Hills district, Meghalaya

\begin{tabular}{|c|c|c|c|c|}
\hline \multirow{2}{*}{ Treatments } & \multicolumn{2}{|c|}{$\begin{array}{l}\text { Chlorophyll content in leaves } \\
(\mathrm{mg} / \mathrm{g})\end{array}$} & \multirow{2}{*}{$\begin{array}{c}\text { Carotenoid } \\
\text { content in fresh } \\
\text { petals } \\
(\mathrm{mg} / \mathbf{1 0 0 g})\end{array}$} & \multirow{2}{*}{$\begin{array}{c}\text { Carotenoid } \\
\text { content in dry } \\
\text { petals } \\
(\mathbf{m g} / \mathbf{1 0 0 g})\end{array}$} \\
\hline & $\begin{array}{c}\text { Chlorophyll } \\
\text { A }\end{array}$ & Chlorophyll B & & \\
\hline $\mathrm{T}_{1}$ Control (100\% RDF) & 39.57 & 50.79 & 11.29 & 8.53 \\
\hline $\mathrm{T}_{2}$ Azospirillum $+75 \% \mathrm{RD} \mathrm{N}+100 \% \mathrm{RD} P$ and $\mathrm{K}$ & 39.68 & 51.94 & 11.05 & 10.09 \\
\hline $\mathrm{T}_{3}$ Azotobacter $+75 \% \mathrm{RD} \mathrm{P}+100 \% \mathrm{RD} \mathrm{N}$ and $\mathrm{K}$ & 39.48 & 45.71 & 11.43 & 8.54 \\
\hline $\mathrm{T}_{4} \mathrm{FYM}+50 \% \mathrm{RDF}$ & 39.57 & 49.27 & 11.56 & 7.82 \\
\hline $\mathrm{T}_{5}$ Vermicompost $+\mathbf{5 0 \%}$ RDF & 39.16 & 41.17 & 11.34 & 10.11 \\
\hline $\mathrm{T}_{6}$ Azospirillum + FYM + 50\% RDF & 39.41 & 47.68 & 11.50 & 9.76 \\
\hline $\mathrm{T}_{7}$ Azospirillum + vermicompost + 50\% RDF & 39.45 & 47.01 & 11.34 & 9.63 \\
\hline $\mathrm{T}_{8}$ Azotobacter + FYM + 50\% RDF & 39.64 & 55.13 & 11.54 & 9.77 \\
\hline T9Azotobacter + vermicompost + 50\% RDF & 39.72 & 48.43 & 11.34 & 9.76 \\
\hline $\begin{array}{c}\mathrm{T}_{10} \text { Azospirillum }+ \text { Azotobacter }+50 \% \text { RD N and P }+ \\
100 \% \text { RD K }\end{array}$ & 39.72 & 57.39 & 11.28 & 11.30 \\
\hline $\mathrm{T}_{11}$ Azospirillum + Azotobacter $+\mathrm{FYM}+50 \% \mathrm{RDF}$ & 39.79 & 61.92 & 11.58 & 11.37 \\
\hline $\begin{array}{c}\mathbf{T}_{12} \text { Azospirillum }+ \text { Azotobacter }+ \text { vermicompost }+ \\
\mathbf{5 0 \%} \text { RDF }\end{array}$ & 39.65 & 57.76 & 11.65 & 9.18 \\
\hline CD at 5 per cent & NS & 2.91 & 0.55 & 0.80 \\
\hline CV $(\%)$ & 1.88 & 3.36 & 2.88 & 4.89 \\
\hline
\end{tabular}




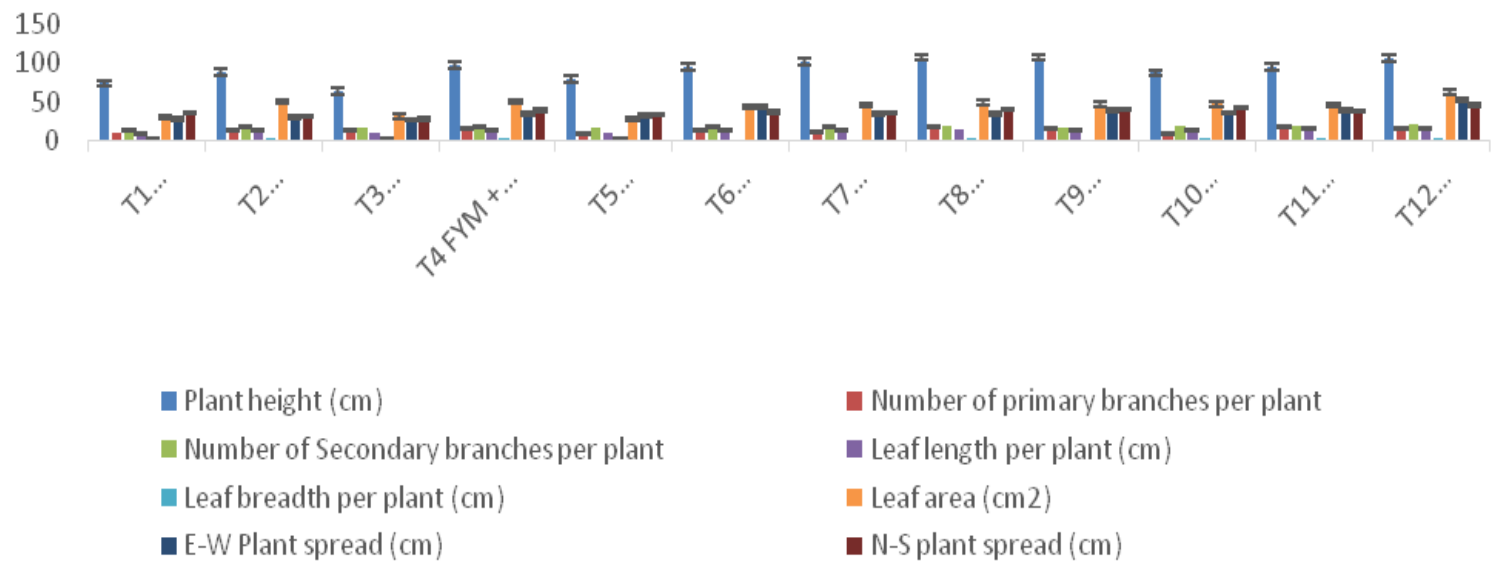

Fig.1 Effect of integrated nutrient management on vegetative parameters of marigold

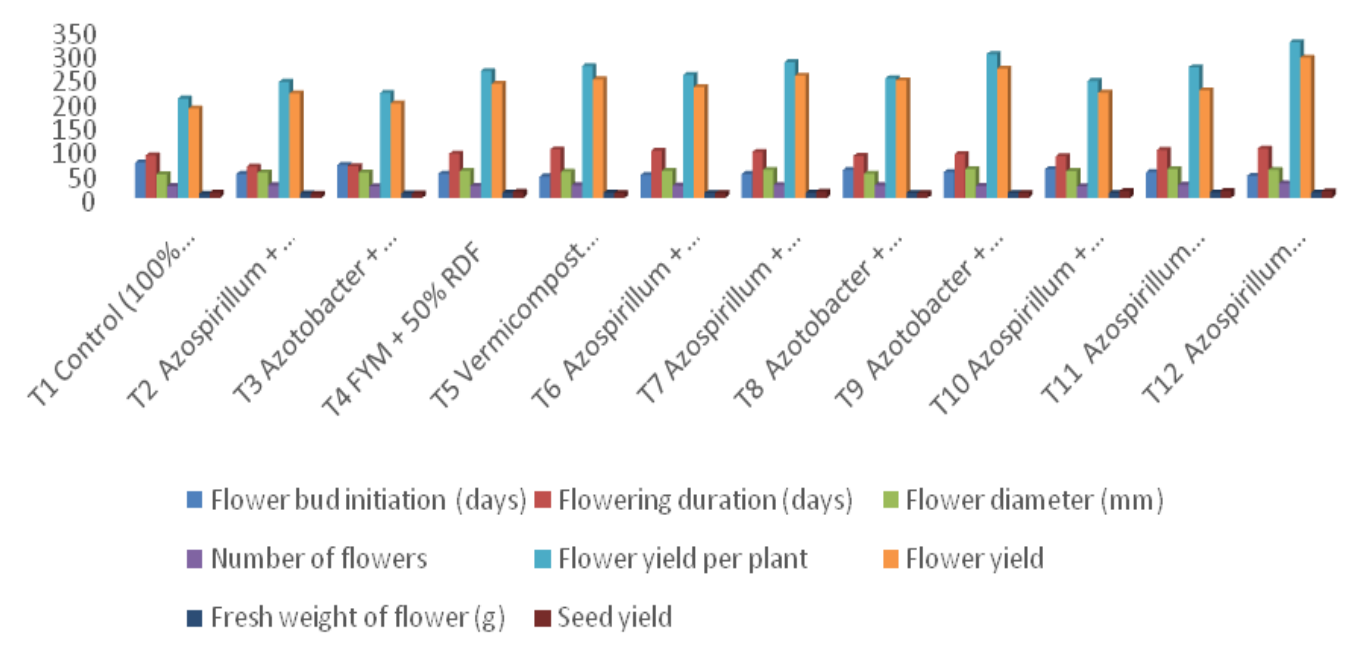

Fig.2 Effect of integrated nutrient management on flower parameters of marigold

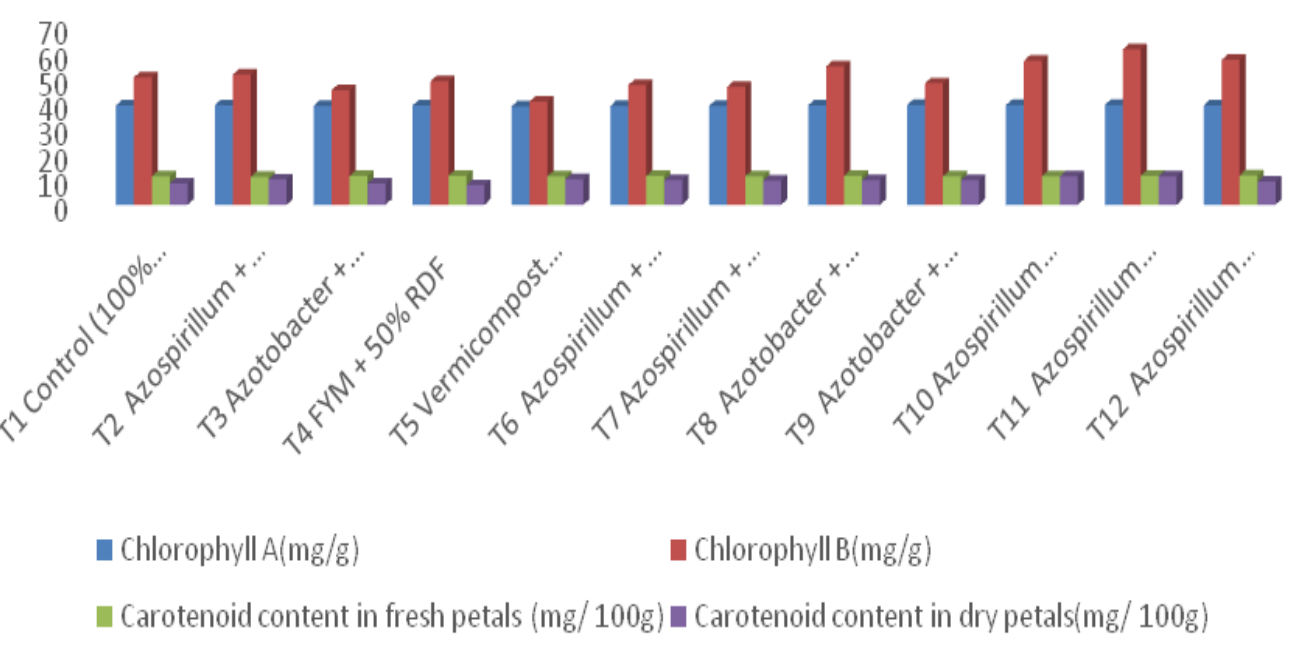

Fig.3 Effect of integrated nutrient management on bio-chemical parameters of marigold 
Maximum carotenoid content in fresh petal was obtained in Azospirillum + Azotobacter + Vermicompost $+50 \%$ RDF (11.65mg/100g) which was on par with Azospirillum+ Azotobacter + FYM + 50\% RDF (11.58 mg/100g). However, Azospirillum+ Azotobacter + FYM $+50 \%$ RDF produced maximum carotenoid contents in dried petal (11.37 mg/100g) followed by Azospirillum+ Azotobacter + Vermicompost $+50 \%$ RDF $(9.18 \mathrm{mg} / 100 \mathrm{~g})$ and Azotobacter $+75 \% \mathrm{RD}$ 'P'+ 100\% RD 'N'\&'K' (8.54 mg/100g). The application of vermicompost and manure compost reduced the harmful effects of water deficit and increased the chlorophyll and carotenoid content in pot marigold (Shakib et al., 2019).Kumar and Sharma (2013) also showed significant response towards carotenoid contents in fresh and dried petal of marigold influenced by organic manure.

The present experiment reveals that the addition of organic manures viz. FYM, vermicompost and biofertilizers along with RDF had a positive effect on the vegetative, flowering and yield characters of marigold.It was apparent through entire investigation that Azospirillum + Azotobacter + Vermicompost $+50 \%$ RDF and Azospirillum+ Azotobacter + FYM $+50 \%$ RDF application was significantly associated for growth, flowering, yield and quality parameters of marigold. Use of adequate organic manures and biofertilizers enhanced the vegetative, flowering, yield and quality parameters of marigold.

\section{References}

Aashutosh, K.M., Malik, S.,Singh, M. K.,Singh, S. P.,Chaudhary,V. and Sharma,V. R. 2019. Optimization of Spacing, doses of Vermicompost and Foliar Application of Salicylic Acid on Growth, Flowering and Soil Health of Chrysanthemum (Dendranthema grandiflora Tzvelev) cv. "Guldasta". International Journal of Agriculture, Environment and
Biotechnology, 12 (3): 213-224.

Ali, T., Rashid, H., Ajmal, B., Sajjad, R. and Ahmad, N. 2014. Investigation of biofertilizers influence on vegetative growth, flower quality, bulb yield and nutrient uptake in gladiolus (Gladiolus grandiflorus L.). International Journal of Plant, Animal and Environmental Science,4(1):94-99.

Bohra, M., Rana, A., Punetha, P., Upadhyay,S. and Nautiyal, B. P. 2019. Effect of organic manures and Biofertilizers on Growth and Floral Attributes of Kamini China Aster. Indian Journal of Horticulture, 76(2): 329. 333.

Chawla, S. L., Patel, M. A., Patil, S., Bhatt, D. and Patel, R. B. 2018. Effect of land configuration and integrated nutrient management on growth, quality and yield of tuberose (Polianthes tuberosa) var. Prajwal. Indian Journal of Agricultural Sciences, 88 (12): 1854-8.

Crowther, F. M. 1935. Comparative trials of calcium cynamide and other nitrogenous fertilizers on crops. Empire Journal of Experimental Agriculture,3: 129-143.

Deshmukh, P. G., Khiratkar, S. D., Badge, S. A. and Bhogle, S. A. 2008. Effect of bioinoculants with graded doses of NPK on growth and yield of gaillardia. Journal of Soil and Crops, 18(1): 212-216.

Dubliya, Y., Vidhya, S. M., Kumar, A., Gallani,R. 2018. Effect of INM on Growth, Flowering and Residual Soil Nutrient Status in Tuberose (Polianthes tuberosa Linn.). Green Farming, 9(1): 154156.

Gomez, K.A. and Gomez, A. A. 2010. Statistical Procedure for Agricultural Research, Wiley India (P) Limited, New Delhi.

Hadwani, M. K., Varu, D. K., Panjiar, N., Babariya, V. J. 2013. Effect of integrated nutrient management on growth, yield and quality of ratoon tuberose (Polianthus tuborosa L.) cv. Double. Asian Journal of Horticulture, 8(2): 448-451.

Keisam, P., Manivannan, K. and Kumar, S. R. 2014. Effect of organic nutrients on 
growth, flowering and yield of Gladiolus grandiflorus L. Asian Journal of Horticulture, 9(2): 416-420.

Kumar, M., Sharma, S. K., Singh, S., Dahiya, D. S., Mohammed, S. and. Singh, V. P. 2006. Effect of farm yard manure and different biofertilizers on yield and nutrients content of marigold $\mathrm{cv}$. PusaNarangi. Haryana Journal of Horticultural Sciences, 35(3\&4): 256-257.

Kumar, S., Momin, B. C. and Dewan, N. 2015.Response of nutrition on growth and flowering of Dendrobium orchids under eastern Himalayan region. Hort Flora Research Spectrum, 4(3): 214-219.

Kumar, P., Kumar, V. and Kumar, D. 2016. Response of INM to plant growth, flower yield and shelf life of African marigold (Tagetes erecta L.) cv. Pusa Basanti Gainda. International Journal of Agriculture Invention, 1(1):108-112.

Kumar, S. and Sharma, S. 2013. Effect of organic manure, drying methods on flower yield and carotenoids content in marigold (Tagetes erecta Linn). Asian Journal of Horticulture, 8(2): 385-390.

Kumari, A., Goyal, R. K., Choudhary, M. and Sindhu, S. S. 2014. Effect of different nitrogen levels and biofertilizers on growth, yield and nutrient content of Chrysanthemum. Annals of Agricultural Research, 35(2): 156-163.

Mittal, R., Patel, H. C., Nayee, D. D. and Sitapara, H. H. 2010. Effect of integrated nutrient management on growth and yield of African marigold (Tagetes erecta L.) cv. 'Local' under middle Gujarat agro-climatic conditions. Asian Journal of Horticulture, 5(2): 347-349.

Munikrishnappa, P.M., Katimani, K.N. and Ravikumar, M. 2004. Effect of vermicompost on growth and yield of tuberose (Pollianthus tuberosa L.) under semiarid tropics of north Karnataka. National symposium on Recent Trends and Future Strategies of Ornamental Horticulture, University of Agricultural Sciences, Dharwad.

Panchal, R. V., Parekh, N. S., Parmar, A. B. and
Patel, H. C. 2010. Effect of biofertilizers and nitrogenous fertilizer on growth, flowering and yield of annual white chrysanthemum (Chrysanthemum coronarium L.) under middle Gujarat agroclimatic conditions. Asian Journal of Horticulture, 5(1): 22-25.

Pandey, S.K., Kumari, S., Singh, D., Singh, V.K. and Prasad, V. M. 2017. Effect of biofertilizers and organic manures on plant growth, flowering and tuber production of dahlia (Dahlia variabilis L.) cv. S.P. Kamala. International Journal of Pure and Applied Bioscience, 5(2): 549-555.

Parya, C., Pal, B. K. and Biswas, J. 2010. Influence of integrated nutrient management on flower production efficiency, behavior and quality of golden rod. Environment and Ecology, 28(4): 2203-2205.

Pooja, G. S. and Kumari, D.S. N. 2012. Response of African marigold (Tagetes erecta L.) to integrated nutrient management. Annals ofBiology,28(1): 6667.

Sadasivam, S. and Manickam, A. 2005. Biochemical Methods, $2^{\text {nd }}$ edition. New Age International (P) Limited, New Delhi.

Sardoei, A. S., Roien, A., Sadeghi, T., Shahadadi, F. and Mokhtari, T.S. 2014. Effect of vermicompost on the growth and flowering of African marigold (Tagetes erecta). American-Eurasian Journal of Agriculture and Environmental Science, 14(7): 631-635.

Shakib, A. K., Nejad, A. R., Mirokhi, A. K. and Jari, S. K. 2019. Vermicompost and Manure Compost Reduce Water-Deficit Stress in Pot Marigold (Calendula officinalis L. cv. Candyman Orange). Compost Science Utilization, 27(1): 61-68.

Sharma, U., Chaudhary, S. V. S. and Chauhan, J. 2009. Effect of sources of applied nutrients on the growth, flowering and seed production of China aster under protected conditions. Haryana Journal of Horticultural Sciences, 38 (3/4):189-190.

Sharma, G., Sahu, N.P. and Shukla, N. 2017. Effect of bio-organic and inorganic nutrient 
sources on growth and flower production of African marigold. Horticulture, 3(1):11.

Shasidhara, G. R. and Gopinath,G.2005. Growth, flowering, yield, quality and economics of calendula (Calendula officinalis L.) as influenced by nutrients and bioinoculants. Journal of Ornamental Horticulture, 8(4):249-253.

Shubha, B.M. 2006. Integrated Nutrient Management for growth, flowering and xanthophyll yield of marigold (Tagetes erecta L.). M. Sc. (Agri.) Thesis, University of Agricultural Sciences, Dharwad.

Singh, L., Gurjar, P., Barholia, A., Haldar, A. and Shrivastava, H. 2015. Effect of organic manures and inorganic fertilizers on Growth and flower yield of marigold (Tagetes erectaL.) var. Pusa Narangi Gainda. Plant Archive, 15(2): 779-783.

Singh, P., Prakash, S., Kumar, M., Malik, S., Singh, M.K. and Kumar, A. 2015. Effect of integrated nutrient management (INM) on growth, flowering and yield in marigold (Tagetus erecta L.) cv. PusaBasanti. Annals of Horticulture, 8(1): 73-80.

Swaroop, K., D. V. S. Raju, V. K. Sharma and T. K. Das. 2017. Influence of Integrated Nutrient Management on Flowering, Corm Productivity and Economic Performance of Gladiolus. Journal of Ornamental Horticulture, 20(3-4): 132-138.
Syamal, M. M., Dixit, S. K. and Kumar, S. 2006. Effect of bio-fertilizers on growth and yield in marigold. Journal of Ornamental Horticulture, 9(4): 304-305.

Thumar, B. V., Barad, A. V., Neelima, P. and Bhosale, N. 2013. Effect of integrated system of plant nutrition management on growth, yield and flower quality of African marigold (Tagetes erecta L.) cv. Pusa Narangi. Asian Journal of Horticulture, 8(2): 466-469.

Tomar, K. S., Kumar, S., Shakywar, R. C. and Pathak, M. 2013. Effect of spacing and nitrogen levels on growth, flowering and yield parameters of African marigold (Tagetes erecta L.) cv. Dwarf Orange. Journal of Ornamental Horticulture,16 (1\&2): 70-74.

Yadav, K. S., Pal, A. K., Singh, A. K., Yadav, D. and Maurya, S. K.2017. Effect of different biofertilizers on growth and flowering of marigold. Journal of Pharmacology and Phytochemistry,7(1): 1548-1550.

Zaredost, F., Hashemabadi, D., Ziyabari, M.B., Torkashvand, A.M., Kaviani, B. Solimandarabi, M.J. and Zarchini, M. 2014. The effect of phosphate bio-fertilizer (Barvar-2) on the growth of marigold. Journal of Environmental Biology, 35(2):439-443.

\section{How to cite this article:}

Anu Seng Chaupoo and Sunil Kumar. 2020. Integrated Nutrient Management in Marigold (Tagetes erecta L.) cv. Pusa Narangi Gainda. Int.J.Curr.Microbiol.App.Sci. 9(05): 2927-2939. doi: https://doi.org/10.20546/ijcmas.2020.905.336 